\title{
SOCIO-ECONOMIC EFFECTS OF INDUSTRIALIZATION IN THE SOCIETY
}

\section{MUHAMMAD BELLO MUHAMMAD, RAHIMAH ABDUL AZIZ YEW}

Faculty of Social Sciences and Humanities, Department of Anthropology and Sociology, Social, Environment and Developmental Sustainability Research Centre, Universiti Kebangsaan, Malaysia

The main aim of the paper is to look at the socio-economic impact of industrialization on the society. Looking through the various works of sociology scholars on how industrialization brings about social inequality and even differentiation among families in the society. This will bring out the pros and cons of industrialization on the social and economic aspects of the society. Content analysis was used to critically review the literature and other secondary sources of data. Functionalist perspective was used in analyzing the study. The outcome of the study is to evaluate the benefits and disadvantages of industrialization in the society and proffer solutions in the form of social policies in order to ameliorate the situation and bring about long-lasting sustainability.
\end{abstract}

KEYWORDS: Industrialization, Social Inequality, Differentiation, Socio-Economic \& Society

Received: May 28, 2018; Accepted: Jun 18, 2018; Published: Aug 11, 2018; Paper Id.: IJEEFUSAUG20183

\section{INTRODUCTION}

In the pre-industrial period, the source of income was mainly from agriculture, and economic status and prestige depended on the size of arable land holdings. Due to the sudden change in the economy, some people were attracted to new and economically advantageous occupations while others were forced to adapt to new types of jobs. The fact that the intergenerational inflow of employers is relatively high due to the increased employment opportunities resulting from the rapid growth of industry in this formerly agricultural area. There is also mobility between generations, with the younger generations moving from the father's occupations to new and different work. In the past, a son usually followed the occupation of his father who often trained him for this kind of job. The extensive mobility, geographical and economic, appropriate to industrialization tends to reduce extended family identification.

The position of the women has changed considerably particularly with regard to their work. Previously, their work was exclusively domestic and agricultural. Today, it is not uncommon for women to work away from home. The new situation has arisen for two reasons: (1) the increased employment of women in the modern industry and (2) the necessity for women to work due to the high cost of living and growing needs of the family. The rising cost of living and the multiplying needs of the family have made it more and more difficult for the husband alone to support the family. The general trend today is to allow women to accept employment outside the home. Given the changing social structure due to industrialization, the authority of women is likely to increase because of their active role in obtaining part of the family income. The changes are largely tailored by employment opportunities. 
The residential distance resulting from the shifting of occupation limits the interaction frequency. The traditionally strong family ties have been weakened because family members, e.g. brothers and sisters, may be working in different and far distant places. Whereas previously the members of a family all lived together in one house or in the same village or town, they are now widely scattered. These new nuclear families find and create new relationships with other people in the localities where they work and so gradually loosen their ties and contacts with their own families. Industrial employment necessitates individual mobility, both physical and occupational, and so relatives may be separated from one another both geographically and socially. As a result of this geographical mobility, it is not possible to interact with a wider kin group. The geographical distribution of occupations may contribute indirectly to the breakup of the extended family relationships. These arguments can be supported by the more general analysis of Parsons (1949), who points out that occupational mobility is antithetical to extended family relations. Stuckert (1960) reports that vertical mobility is also associated with less visiting within extended families, less family identification, less use of the family as a reference group and less concern for family unity.

The industrialization of the world changed the manner in which people lived and the way societies interact in a variety of ways including quality of life, economic power, and political repercussions. The landscape of the world morphed from a primarily agrarian culture to mechanical. The new industrialization required people to re-think the cultural norms and challenge the government to adapt to the new way of life as well. Industrialization changed society from agrarian to mechanical, meaning the majority of sustainable jobs moved to larger cities. This created several problems for the working class. Living conditions during the early phases of industrialization were poor. Cities, unable to handle the influx of workers, hastily erected poorly constructed and crowded apartment buildings or other residences. The workers often lived close to the factories and were surrounded by pollution more often than not. The work was also dangerous with little government oversight in new industries. Workers, having yet to form unions, had little bargaining power with managers leaving the workers vulnerable to unsafe conditions.

\section{LITERATURE REVIEW}

Various anthropologists and sociologists (Parsons 1949; Burgess and Locke 1953; Goode 1963, 1964, 1968) concentrate on this approach. Goode $(1963,1964)$ affirms that family systems throughout the world are generally moving in the direction of the 'conjugal pattern', and that there is a lack of 'fit' between the extended family and industrialization. In his view (1964: 109), the integration of the family weakens because the wage-job is an individualistic affair, and because members of the kin group no longer live close together. Parsons (1949) seems to go further in suggesting that the isolated nuclear family is the only type which is functional for urban industrial society. Stuckert (1960) notes that as industrialization has moved forward the individual is more likely to be able to make his own way without his kin.

Evidence by different writers has shown that the establishment of industries especially in the rural areas is an important strategy for transforming the rural economy. "Industrialization removed many functions of the family and as society industrialized; its institutions including the family undergo differentiation" (Parsons, 1951). He further contended that, this should be reviewed as part of the general decline on the role of the family, but should be noted too that an industrial society still logically require stable family system, to maintain balance personalities in the men who are subjected to its competitive demands and to ensure the successful socialization of the whole society. 
Parsons ideas have an important contribution to this area of discussion. He has shown how industrialization brings changes in the family structures of the community where the industry is located. Though, Parson's fails to consider changes at the individual level. Linton (2001) tends to agree with Parsonsviews, but approached the problem from an individual level rather than the social point of view. He sees changes in the family roles from the fact that industrialization allowed both men and women great freedom from normative and direct economic control of others. In consequence, the individual is able to; within limits vary his family relationship.

More so, Moore (2001) also developed his idea from Linton and Parsons point of analysis, that, the extensive mobility both geographical and socially appropriate to industrialization, and the industrial society has negative consequences for extended kinship systems which later breaks the close ties between adult generation and adult siblings. Under this condition, the social responsibility of kinsmen beyond the nuclear family of parents and their children weakens the permissive rather than obligatory roles. Furthermore, extensive family disorganization is likely to accompany the breakdown of traditional order and the incomplete establishment of new institutions. Thus mate selection, parent-child relationship etc are affected by the "individualism" that industrialization and the attendant modernization foster.

Based on the above literature, it would be understood that locating industries in a community usually brings about some changes. However, Thompson (1996) maintain that industry brings with it more problems to the community than the community ever had faced before. Therefore, Parson (1951), Linton (2001), Moore (2001) and Thompson (1996) have contributed in seeing how the location of industry in any community can bring social changes in the family structure of that community. These scholars fail to see the changes in wider perspectives. That is to say, they narrow down their argument to the family rather than the community in general.

On the other hand, Frazer (cited in Blumer, 2001) looked at the effect of traditional order according to him high mobility is a feature of industrial communities. For him, high mobility and good citizenship do not go together. In human communities with a large number of settled residents, one get settled in an orderly responsible life. But where there is high mobility, the small proportion of old resident's losses grip and the high mobile section do not take on settled community behavior. On this note, he maintained that in this type of community having features similar to industrial communities, workers are tempted to spend their leisure hours in the local bars, frequent gambling and join those who describe themselves as the action troopers of local political parties.

Frazer (cited in Blumer, 2001), contribution shows that industrial location does affect the traditional order of the community where the industry is located, but he fails to show us the extent to which the traditional order is altered. Similarly, Moore (2001) argued that an industrial community normally assembles people from different ethnic groups, tribes, countries and cultural zones. He concluded that in such a situation, informal social control is likely to be radically weakened. In addition, for some inhabitants of such communities, the loss of intimate bonds with the meaningful order like family relations with whom such inhabitants have emotional ties will produce various symptoms. Alcoholism, various mental disorder, and drug addiction may well increase in the case of rapid economic changes, and may persist as various economic and social dislocations exert their role on those who do not adapt well to the process.

In addition to Moore's idea, Blumer (2001) argued that industrialization from the view of sociologist undermines traditional order. Through the displacement of existing occupations, a shift of production from homes and villages to factories, generating migration and urbanization, fostering social mobilization, introducing monetary and contracted relations as well as promoting secular and rational perceptions. Such change tends to have an effect on the community of 
the prevailing class structure, status disintegration, and role-arrangements, transforming of traditional tastes and eroding of established values.

In essence Frazer (cited in Moore 2001) and Blumer's (2001) contribution appear relevant literature to this work. They looked at the changes as they affect the functional order with issues like changes in behavior as a result of life among residents who no longer regard community values because of the weakened social control which the industrialization process brought through migration of people from other places to the area, yet they did not pay much emphasis on the economic aspect of change. Consequently, in the study by UNESCO (1984), it was observed that industrialization causes the uncontrollable rate of an exodus of people from the rural areas and consequently leaves the production of food supplies in the hands of the less enterprising members of the community whose burden grows heavier. Thus, industrialization entails the reduction of a substantial proportion of the population directly engaged in agriculture. Similarly, as a result of the location of industry in an area, rural women and men have typically pushed off the land and into wage employment by social and economic as well as political pressure, the landless, the hungry, the politically powerless, the socially disaffected becomes the first industrial recruits. As a result of this, there is a change in specialization on the part of the rural women and men, thereby affecting the occupational structure of the community (Chinoy 1985). The studies by UNESCO (1984) focus on the economic effect of industry on the community but the ideas fail to touch environmental aspect of change.

Miller (1984) shows that the social and economic effect of community development by industry lies in the infrastructure of the community, but to prove that social and economic development does not only lie on community infrastructure. Moore (2001) asserted that one effect of the industry to develop the community is the provision of employment opportunities and sources of revenue of the inhabitants through new business opportunities in the community.

Furthermore, Banda argued with respect to the provision of employment opportunities that "not only do environment, infrastructures and manpower affect the state of the natural environment; it also affects the formation of infrastructure and manpower". He also said that, not only the development of infrastructural facilities by the new productive activities in the area, it also helps in improving the living condition of the resident in the community. The ideas of these scholars are basically on sources of income for the residents of the community where the industry is located. In other words, residents should have the economic benefit through the existence of the industry in the areas (Part \& et al, 2000).

Hoselitz argued that, apart from providing employment opportunities for the residents of the community, the effect of the industry should be viewed from the social class structure. He was of the opinion that industrialization provides a new set of social positions, he also argued that during the early phases of the industrialization process new and sharp distinctions in social status emerged and this in the long - run, as a result of the differentiation gives rise to more conspicuous patterns of social stratification in the community (Moore, 2001). Miller (1984) was also of the view that industry influences the community in the shaping of the social class structure in the community.

An industrial society requires greater mobility, both occupational and spatial. As people move up and down and across the frame of occupations and skills, the lines demarcating caste or community begin to go. It becomes harder to keep track of a person's social position. Furthermore, the social position begins to correspond less and less with a person's income and his importance in the economy. As incomes and economic status become scrambled, it becomes increasingly difficult to take seriously the ancestral position of the citizens of the industrial world. When moving from place to place is slow or infrequent, the society can keep track of each person's traditional position and when movement is rapid and 
widespread the fine gradations tend to disappear. In India today in the large cities the caste position of each person is still definitely recognized, but the caste blocks in the cities are far larger and more inclusive than they are in the villages, and the importance of sub-castes much less. In addition, the castes are to a large extent local. The process of industrialization affects castes from different, localities together so that it is not easy to establish the essential hierarchy among them. When it is impossible to establish the hierarchical relationships among the castes one of their major functions in organizing the social relationships between people ceases, and there is that much less purpose in maintaining the distinctions.

\section{METHOD}

Secondary data was used to systematically review relevant scholarly literature through mapping and forming a narrative method. In order to address the issue of social inequality, Functionalist perspective was used in this paper.

\section{RESULTS AND DISCUSSIONS}

Generally, the industrial sector is faced with many problems. The most obvious is that of air pollution which has serious and dangerous side effects of economic growth. Industrial complex is responsible for the massive generation of emissions, waste, and pollutants.

The design of successful remedies for correcting large-scale production requires a thorough analysis of the multiple causes of pollution. Since pollution can be (and in most cases is) health hazardous, extra cost generating and undesirable, there is the need to control pollution activities (Cahill, 2002).

Different views emerged to question the concept of industrialization regarding air pollution on both economic and social grounds. This could be traced from the assertion made by Seers (1963) that the emphasis on industrialization has been largely due to three basic fallacies arising from contentions on the relationship between industry and national economic growth.

The first fallacy as noted by Seers is, in the past, some protagonist of a vast road to economic development advocated that industrial development is in some ways better and more important than agricultural development. This they claimed is due to the fact that agricultural development is usually not as rapid as industrial. Samson, et al (2001) argued that there should be no question of choosing between agricultural and industrial development. They stressed that neglecting agriculture in the development process can be quite as serious as neglecting industries. An example is a Nigerian case where agriculture was woefully neglected with the discovery of oil. This is indeed one of the causes of the Nigerian food crisis.

Another aspect of the industrialization fallacy is the false belief to the effect that manufacturers are capable of providing a great deal of employment. Considerable evidence has shown that a rapidly growing manufacturing sector does not necessarily provide much employment, Balogh (1966), studying the impacts of industries on employment in developing countries revealed that more than seventy percent(70\%) of the working population is employed in the agricultural sector and not the industrial sector in the rural areas. He also argued that industries do not in a way to create employment for the rural people due to the fact that some industries require entrepreneurial, managerial and working talent which are lacking among the rural people.

The third Fallacy states that industrialization will cause the expenditure of foreign exchange to fall. It has been shown that it generally does not. Olabisi (1980), in a study of industrialization in the developing countries, showed that 
expenditure on the foreign exchange may not fall since industrialization in developing countries involves the substantial importation of machines spare parts, materials etc. Thus, the industrialization fallacy has been corrected by Francis (2003), who argued that "the rising incomes resulting from industrial development will permit a substantial expansion of employment in the economy as a whole," and that industrialization will make possible for incomes to rise faster than imports and will thus eventually lessen the dependence on the primary products.

\section{CONCLUSIONS}

It becomes useful at this juncture to raise the question whether a planned location of industries is sound on both economic and social grounds. Studies carried out on the nature of industries located in rural areas revealed that this may result to problems of economic unavailability and vested interests largely influenced by political considerations which can make rural industries mere dead ends as soon as they are established (Samson, et al 2001).

Likewise, it is important to note that the same industrialization that led to the revolution in medicine by producing new drugs, has also given birth to the resistant strain of diseases, e.g malaria, cholera e.t.c.

Arguing on social grounds is a number of writers who are very much concerned with social justice. Paul (2001) argued that social objectives such as income distribution and job creation are more important than the rise in some abstract index number to which industrial growth contributes and has rapaciously used up exhaustible natural resources, supplies of energy and this rapid growth increases in equally and proceeds with regards of damage inflicted upon its victim.

On the basis of the findings and the conclusion is drawn from this study, the following recommendations were offered.

- A government should create and enforce policies that are environmentally friendly which will protect the society's interest and better their living condition.

- Industries should be made to provide social amenities in the society such as bore-holes, health centers, schools, thereby enhancing their socio-economic development.

- The Industries should have a good rapport with the host society by providing a significant number of the inhabitants with permanent employment which will be a motivating factor for the individuals.

- A government should make Industries to compensate the damages done to the society by paying the medical bills of those affected, etc.

\section{REFERENCES}

1. Balogh, T. (1966) The Economics of Poverty, London: Chelsea Pub. CompanyLtd.

2. Blumer, H. (2001) Industrializaton and The Traditional Order, Sociology and Social Research: An International Journal, vol.4, no.2.

3. Burges, E. W. and H. J. Locke (1953) The Family. New York: American Book Co.

4. Cahill, M. (2002) The Environment and Social Policy. Padstow, Cornwall. T.J. International Ltd.

5. Chinoy,E.(1985) An Introduction to Sociology 2nd Edition, London: Fennesse Press.

6. Francis, C.J. (2003) Industry and Economic Development. Manchester: Lee and Co. Limited. 
7. Goode, W. J. (1963) World Revolution and Family Patterns. New York: The Free Press.

8. Goode, W. J. (1964) The Family. New Jersey: Prentice-Hall.

9. Goode, W. J. (1968) Industrialization and Family Change. In Industrialization and Society.(B. F. Hoselitz and W. E. Moore, eds.). U.N.E.S.C.O.: Mouton.

10. Parsons, T. (1949) The Social Structure of the Family. In The Family: Its Function and Destiny.(R. N. Anshened.). New York: Harper and Row.

11. Tiwari, N., Singh, S. S., Singh, R., \& Charmkar, N. K. (2018). Effect of Organic-Cum-Inorganic Sources of Nutrients on Growth, Yield and Economical Gain from Guava.

12. Parson, T. et al (1951) Family Socialization and Interaction Process. New York: Macmillan.

13. Part, D. R et al (2001) The Sociology of Industry. London: George Allen andUnwin Ltd.

14. Paul, S. (2001) "Industrialization in a Unified Development Strategy", A PaperPresented at UNIDO Conference On Industrial Development Strategy in Johannesburg, South Africa.

15. Linton, R. (2001) The National History of the Family, London: Anghem Edition.

16. Miller, D. (1984) Industrialization and Society, London: Pluto Press.

17. Moore, W.C. et al (2001) Industrialization and Society of Chicago. Chicago:Prentice-Hall.

18. Olabisi, O. (1980) Industrialization of the Developing Countries. Ibadan:Unversity Press.

19. Samson, O. et al (2001) Elements of Rural Economics. Ibadan: University Press.

20. Seers, D. (1963) The Role Of Industry in Development: Some Fallacies, A Journal of Modern African Studies, Vol. 1 No. 4.

21. Stuckert, R. P. (1960) Occupational Mobility and Family Relationships. A Modern Introduction to the Family (N. W. Bell and E. F. Vogel, eds.). London, Routledge and Kegan Paul.

22. Thompson, L. (1996) The Challenge Of Change. New York: Penguin Press.

23. UNESCO (1984) Research On Effect Of Industry And Community. 
